\title{
Front Matter: Volume 7184
}

, "Front Matter: Volume 7184," Proc. SPIE 7184, Three-Dimensional and Multidimensional Microscopy: Image Acquisition and Processing XVI, 718401 (20 March 2009); doi: 10.1117/12.819869

SPIE. Event: SPIE BiOS, 2009, San Jose, California, United States 


\section{Three-Dimensional and Multidimensional Microscopy: Image Acquisition and Processing XVI}

Jose-Angel Conchello

Carol J. Cogswell

Tony Wilson

Editors

26-29 January 2009

San Jose, California, United States

Sponsored and Published by

SPIE

Volume 7184

Proceedings of SPIE, 1605-7422, v. 7184

SPIE is an international society advancing an interdisciplinary approach to the science and application of light. 
The papers included in this volume were part of the technical conference cited on the cover and title page. Papers were selected and subject to review by the editors and conference program committee. Some conference presentations may not be available for publication. The papers published in these proceedings reflect the work and thoughts of the authors and are published herein as submitted. The publisher is not responsible for the validity of the information or for any outcomes resulting from reliance thereon.

Please use the following format to cite material from this book:

Author(s), "Title of Paper," in Three-Dimensional and Multidimensional Microscopy: Image Acquisition and Processing XVI, edited by Jose-Angel Conchello, Carol J. Cogswell, Tony Wilson, Proceedings of SPIE Vol. 7184 (SPIE, Bellingham, WA, 2009) Article CID Number.

ISSN 1605-7422

ISBN 9780819474308

Published by

SPIE

P.O. Box 10, Bellingham, Washington 98227-0010 USA

Telephone +1 3606763290 (Pacific Time) · Fax +1 3606471445

SPIE.org

Copyright (C) 2009, Society of Photo-Optical Instrumentation Engineers.

Copying of material in this book for internal or personal use, or for the internal or personal use of specific clients, beyond the fair use provisions granted by the U.S. Copyright Law is authorized by SPIE subject to payment of copying fees. The Transactional Reporting Service base fee for this volume is $\$ 18.00$ per article (or portion thereof), which should be paid directly to the Copyright Clearance Center (CCC), 222 Rosewood Drive, Danvers, MA 01923. Payment may also be made electronically through CCC Online at copyright.com. Other copying for republication, resale, advertising or promotion, or any form of systematic or multiple reproduction of any material in this book is prohibited except with permission in writing from the publisher. The CCC fee code is 1605 $7422 / 09 / \$ 18.00$.

Printed in the United States of America.

Publication of record for individual papers is online in the SPIE Digital Library.

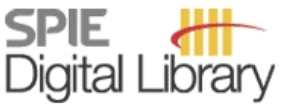

SPIEDigitallibrary.org

Paper Numbering: Proceedings of SPIE follow an e-First publication model, with papers published first online and then in print and on CD-ROM. Papers are published as they are submitted and meet publication criteria. A unique, consistent, permanent citation identifier (CID) number is assigned to each article at the time of the first publication. Utilization of CIDs allows articles to be fully citable as soon they are published online, and connects the same identifier to all online, print, and electronic versions of the publication. SPIE uses a six-digit CID article numbering system in which:

- The first four digits correspond to the SPIE volume number.

- The last two digits indicate publication order within the volume using a Base 36 numbering system employing both numerals and letters. These two-number sets start with 00, 01, 02, 03, 04, $05,06,07,08,09,0 A, 0 B \ldots 0 Z$, followed by 10-1Z, 20-2Z, etc.

The CID number appears on each page of the manuscript. The complete citation is used on the first page, and an abbreviated version on subsequent pages. Numbers in the index correspond to the last two digits of the six-digit CID number. 


\section{Contents}

vii Conference Committee

\section{MICROTOMOGRAPHY, POLARIZED LIGHT, AND OTHER MICROSCOPY METHODS}

7184 OA FPGA-based electronics for confocal line scanners with linear detector arrays [7184-10] S. Abeytunge, R. Toledo-Crow, M. Rajadhyaksha, Memorial Sloan-Kettering Cancer Ctr. (United States)

$7184 \mathrm{OB} \quad$ Coherence measurements applied to critical and Köhler vortex illumination [7184-51] D. P. Brown, T. G. Brown, Univ. of Rochester (United States)

7184 OC Dual objective fluorescence microscopy for single molecule imaging applications [7184-42] S. Ram, The Univ. of Texas Southwestern Medical Ctr. at Dallas (United States); P. Prabhat, The Univ. of Texas Southwestern Medical Ctr. at Dallas (United States) and The Univ. of Texas at Dallas (United States); E. S. Ward, The Univ. of Texas Southwestern Medical Ctr. at Dallas (United States) R. J. Ober, The Univ. of Texas Southwestern Medical Ctr. at Dallas (United States) and The Univ. of Texas at Dallas (United States)

\section{VISUALIZATION OF UNSTAINED TRANSPARENT SPECIMENS}

7184 OD 3D effects in DIC images of extended objects [7184-11] H. Sierra, C. A. DiMarzio, D. H. Brooks, Northeastern Univ. (United States)

7184 OF Comparison of optical quadrature microscopy and Shack-Hartmann wavefront sensor [7184-13]

Y. G. Patel, W. C. Warger II, Northeastern Univ. (United States); J. Ballesta, Imagine Optic SA (France); C. A. DiMarzio, Northeastern Univ. (United States)

7184 OG Accurate phase measurements for thick spherical objects using optical quadrature microscopy [7184-14]

W. C. Warger II, C. A. DiMarzio, Northeastern Univ. (United States)

\section{NEW METHODS IN FLUORESCENCE MICROSCOPY}

7184 Ol 3D microscopy with a double-helix point spread function (Invited Paper) [7184-16] S. R. P. Pavani, R. Piestun, Univ. of Colorado at Boulder (United States)

$71840 \mathrm{~J}$ Hyperspectral image correlation for monitoring membrane protein dynamics in living cells [7184-17]

R. W. Davis, B. Carson, H. D. T. Jones, M. B. Sinclair, Sandia National Labs. (United States)

7184 OM Efficient confocal microscopy with a dual-wedge scanner [7184-21]

W. C. Warger II, S. A. Guerrera, Northeastern Univ. (United States); Z. Eastman, Lucid, Inc. (United States); C. A. DiMarzio, Northeastern Univ. (United States) 
$7184 \mathrm{OP}$ Multi-wavelength digital holographic tomography based on spectral interferometry [7184-23]

L. Yu, Z. Chen, Univ. of California, Irvine (United States)

7184 OR Application of 3D tracking, LED illumination and multi-wavelength techniques for quantitative cell analysis in digital holographic microscopy [7184-25]

B. Kemper, S. Kosmeier, P. Langehanenberg, S. Przibilla, C. Remmersmann, S. Stürwald,

G. von Bally, Westfälische Wilhelms-Univ. Münster (Germany)

7184 OS Arbitrary two-dimensional multiphoton excitation patterns with temporally focused digital holograms [7184-26]

D. Oron, Weizmann Institute of Science (Israel); E. Papagiakoumou, V. de-Sars, V. Emiliani, Rene Descartes Univ. (France)

\section{COMPUTATIONAL MICROSCOPY}

$7184 \mathrm{OV}$ Unsupervised 3D deconvolution method for retinal imaging: principle and preliminary validation on experimental data [7184-29]

G. Chenegros, L. M. Mugnier, C. Alhenc-Gelas, ONERA-PHASE (France); F. Lacombe, Mauna Kea Technologies (France); M. Glanc, Observatoire de Paris à Meudon, LESIA-PHASE (France); M. Nicolas, ONERA-PHASE (France) and Observatoire de Paris à Meudon, LESIA-PHASE (France)

7184 0X Testing for nonrandom shape similarity between sister cells using automated shape comparison [7184-31]

M. Guo, W. F. Marshall, Univ. of California, San Francisco (United States)

7184 OY Automated analysis of intracellular motion using kymographs in 1, 2, and 3 dimensions [7184-32]

W. B. Ludington, W. F. Marshall, Univ. of California, San Francisco (United States)

\section{SYNTHETIC ILLUMINATION AND SYNTHETIC APERTURES I}

$71840 Z$ Fluorescence microscopy with a coded aperture snapshot spectral imager [7184-33] C. A. Fernandez, A. Wagadarikar, D. J. Brady, Duke Univ. (United States); S. C. McCain, Applied Quantum Technologies (United States); T. Oliver, Duke Univ. (United States)

\section{SYNTHETIC ILLUMINATION AND SYNTHETIC APERTURES II}

718413 Two-dimensional resolution improvement in standing wave microscopy using fast acousto-optic laser scanning [7184-37]

O. Gliko, W. E. Brownell, Baylor College of Medicine (United States); P. Saggau, Baylor College of Medicine (United States) and Rice. Univ. (United States) 
718414 Biological imaging beyond the diffraction limit by saturated excitation (SAX) microscopy [7184-38]

M. Yamanaka, S. Kawano, K. Fujita, N. I. Smith, Osaka Univ. (Japan); S. Kawata, Osaka Univ. (Japan) and RIKEN (Japan)

718415 Imaging properties of saturated excitation (SAX) microscopy [7184-39]

S. Kawano, M. Yamanaka, K. Fujita, N. I. Smith, Osaka Univ. (Japan); S. Kawata, Osaka Univ. (Japan) and RIKEN (Japan)

718417 Live TIRF microscopy at 100nm resolution through structured illumination [7184-41] P. Kner, B. Chhun, E. Griffis, L. Winoto, L. Shao, M. G. L. Gustafsson, Univ. of California, San Francisco (United States)

\section{POSTER SESSION}

718419 Quantifying colocalization of a conditionally active transcription factor FOXP3 in three-dimensional cellular space [7184-44]

T. Abraham, Univ. of British Columbia (Canada); S. E. Allan, M. K. Levings, Univ. of British Columbia (Canada) and Vancouver Coastal Health Research Inst. (Canada)

7184 1B Thickness and index measurements of a transparent specimen by full-field optical coherence microscopy [7184-47]

J. Na, W. J. Choi, H. Y. Choi, S. Y. Ryu, Gwangju Institute of Science and Technology (Korea, Republic of); E. S. Choi, Chosun Univ. (Korea, Republic of); B. H. Lee, Gwangju Institute of Science and Technology (Korea, Republic of)

7184 ID A hybrid global fitting algorithm for decay-associated images from fluorescence lifetime image microscopy data [7184-53]

A. V. Smirnov, C. A. Combs, R. S. Balaban, National Institutes of Health (United States);

K. Tang, Yale Univ. (United States); J. R. Knutson, National Institutes of Health (United States)

Author Index 
Downloaded From: https://www.spiedigitallibrary.org/conference-proceedings-of-spie on 26 Apr 2023

Terms of Use: https://www.spiedigitallibrary.org/terms-of-use 


\title{
Conference Committee
}

\author{
Symposium Chairs \\ James G. Fujimoto, Massachusetts Institute of Technology (United \\ States) \\ R. Rox Anderson, Wellman Center for Photomedicine, Massachusetts \\ General Hospital (United States) and Harvard School of Medicine \\ (United States)
}

Program Track Chairs

Ammasi Periasamy, University of Virginia (United States)

Daniel L. Farkas, Cedars-Sinai Medical Center (United States)

Conference Chairs

Jose-Angel Conchello, Oklahoma Medical Research Foundation (United States)

Carol J. Cogswell, University of Colorado at Boulder (United States)

Tony Wilson, University of Oxford (United Kingdom)

Conference Cochair

Thomas G. Brown, University of Rochester (United States)

Program Committee

G. J. Brakenhoff, Universiteit van Amsterdam (Netherlands) Charles A. DiMarzio, Northeastern University (United States)

Mats G. L. Gustafsson, University of California, San Francisco (United States) and Howard Hughes Medical Institute (United States)

Gordon S. Kino, Stanford University (United States)

Raimund J. Ober, The University of Texas at Dallas (United States)

Rudolf Oldenbourg, Marine Biological Laboratory (United States)

Chrysanthe Preza, The University of Memphis (United States)

Session Chairs

1 Fluorescence Depletion Microscopy

Charles A. DiMarzio, Northeastern University (United States)

2 Microtomography, Polarized Light, and Other Microscopy Methods

Raimund J. Ober, The University of Texas at Dallas (United States) 
3 Visualization of Unstained Transparent Specimens

Raimund J. Ober, The University of Texas at Dallas (United States)

$4 \quad$ New Methods in Fluorescence Microscopy

Thomas G. Brown, University of Rochester Medical Center (United

States)

5 Holographic Methods in Microscopy

G. J. Brakenhoff, Universiteit van Amsterdam (Netherlands)

6 Computational Microscopy

Mats G. L. Gustafsson, University of California, San Francisco (United States) and Howard Hughes Medical Institute (United States)

$7 \quad$ Synthetic Illumination and Synthetic Apertures I

Mats G. L. Gustafsson, University of California, San Francisco (United States) and Howard Hughes Medical Institute (United States)

8 Synthetic Illumination and Synthetic Apertures II

Rudolf Oldenbourg, Marine Biological Laboratory (United States) 